\title{
Evaluation of Acquired Knowledge about Occupational Safety in Dual Education
}

\author{
Ivana Tureková ${ }^{1}$, Roman Hrmo ${ }^{2}$, Iveta Marková ${ }^{3}$, Miroslava Kordošová ${ }^{4}$ \\ ${ }^{1}$ Constantine the Philosopher University in Nitra, Slovakia \\ ${ }^{2}$ DTI University, Dubnica nad Váhom, Slovakia \\ ${ }^{3}$ University of Žilina, Slovakia \\ ${ }^{4}$ Institute for Work and Family Research, Slovakia
}

\begin{abstract}
In Slovakia, dual vocational education and training is based on the cooperation between secondary vocational schools and companies. Companies take full responsibility for the quality of education and training in occupational safety and knowledge of operating activities risks. In our article, we aimed to survey pupils with an attitude questionnaire about the quality and experience with safety and education at the employer's workplace during vocational education and training. Ninety respondents, preparing for their professions in the automotive industry, participated in our survey. The analysis of the questionnaires revealed that the students could not relevantly identify the most significant dangers and risks in the workplaces to which they are exposed in the current work. An essential recommended measure is a high-quality inclusion of these topics into training using activating methods in this process and better methodological and vocational preparation for employers' lecturers.
\end{abstract}

Keywords - Vocational education and training, dual system, risks at work, pupils, employers` lecturers.

\section{Introduction}

The dual vocational education and training (VET) system is a specific and internationally accepted form

DOI: 10.18421/TEM104-39

https://doi.org/10.18421/TEM104-39

Corresponding author: Ivana Tureková,

Constantine the Philosopher University in Nitra, Slovakia.

Email: iturekova@ukf.sk

Received: 08 September 2021.

Revised: 20 October 2021.

Accepted: 28 October 2021.

Published: 26 November 2021.

(c) BY-NC-ND C 2021 Ivana Tureková et al; published by UIKTEN. This work is licensed under the Creative Commons Attribution-NonCommercial-NoDerivs 4.0 License.

The article is published with Open Access at www.temjournal.com of preparing the young generation for their professions. In their essential aspects, dual VET systems abroad are almost the same; they have their standard features, but, of course, we can find differences there as well [1], [2]. Austria, Germany and Switzerland belong to the most successful countries in this area [3]. Thanks to their dual educational systems and intensive apprenticeship programmes, these countries have created a very close connection between their educational systems and industry that is also the goal of the Slovak Republic [4].

In Slovakia, the unemployment rate of persons aged $15-24$ years was $26.5 \%$ in 2015 as opposed to $20.4 \%$ for the EU average [5]. Therefore, the VET started to be implemented since adopting the Law about VET in 2015 due to the changing labour market requirements [6], [7], [8], [9]. The difference between the school vocational education system and the dual education system in the Slovak Republic is shown in Figure 1.

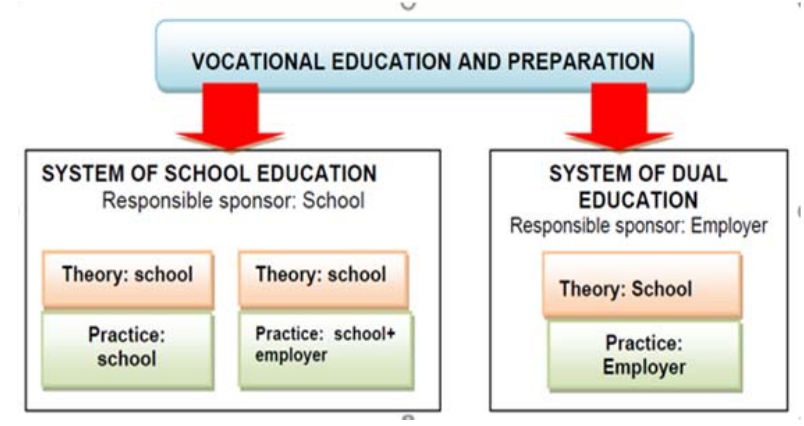

Figure 1. Systems of vocational in the Slovak Republic [9]

According to the law about vocational education, the employer is responsible for the whole practical education [10], [11]. A further benefit is that the employer can set the students' vocational preparation according to his requirements and needs, but at the same time, the employer bears all costs related to its realisation [12], [13].

Dual education provides all the relevant skills and competences needed to perform specific professions, 
including general and transferable competences, which students can apply not only in a given enterprise, but in the whole industry sector and, generally, at the labour market as well [14]. Young people see another positive aspect of earning their own money already during their studies [15], [16].

In dual VET, practical lessons take place at the employer's workplace. Here, employers also train pupils in occupational safety and health, who are their potential employees [17].

At all school system levels, including dual education, the contents and forms of education are adapted to the age of the pupils. The same should apply to OSH education [18], [19]. However, training in the field of occupational safety and health and occupational risk is usually provided by professionals with expertise in adult education.

Every "employee" has to know the legal requirements of safety regulations but he/she also has to be aware of the hazards and risks of professional work. The aim of the survey was to determine the quality of introductory training, knowledge of risks in practical activities from the perspective of dual education students. There was used a questionnaire survey, in which students declared their attitudes to the acquired knowledge, including good practice in the field of accident prevention. The questionnaire also included control questions, which confirmed the high subjectivity of the answers.

\section{Methodology}

The research part aimed to determine the quality of introductory OSH training for pupils in the dual education system. It focused on pupils' knowledge about the OSH regulations and all possible risks at work they do for the employer. We used dialogues with pupils, teachers and observations at workplaces. Using the questionnaire survey, we obtained information from pupils about the quality of their introductory training.

Before the actual survey, three descriptive research questions were formulated:

1. What is the main goal of OSH education of pupils in dual education?

2. Are examples of good practice accident prevention?

3. What forms and methods of education correspond to the age of educators?

\subsection{Selection of a Secondary School for the Execution of the Survey}

We chose a secondary vocational traffic school for our questionnaire survey, which participates in the dual education system. The school provides excellent conditions, and it has good relationships with partner employers. They all try to meet the labour market expectations. On one side, the school provides pupils with preparation for specific professions according to the state educational system. On the other side, the school adjusts its education to the character of professions and vocational activities within the preparation for the given professions following the valid legislation.

Pupils are prepared for occupational performance in several study fields. They finish them with a final school-leaving exam, and they also obtain a vocational certificate (four-year study fields):

- autotronic;

- commercial worker in traffic;

- plant operator of traffic management and economics, traffic management and economics.

Another possibility is a three-year study for the profession of an automotive technician finishing with a vocational certificate in these fields:

- automotive technician - mechanic;

- automotive technician - electrician;

- automotive technician - coachbuilder;

- automotive technician - car painter;

- ship technician.

The school also provides a possibility of further education in the form of a two-year post-secondary education in the following study fields:

- engineering;

- traffic operation;

- sale and service.

Most pupils choose the profession of an autotronic. Graduates of this study field can be successful as automotive engineers, automotive technicians, but they can also work in vehicles diagnostics, including hybrid vehicles. They can also apply their qualifications as plant, service or receiving technicians, car dealers, leading workers in car service stations or workers in technical or emission control stations.

We administered 100 questionnaires to pupils, and out of them, we evaluated 90 filled questionnaires. Pupils answered the questions during our meeting with respondents and teachers' assistance. We explained the research objectives and principles to pupils before they answered the questionnaire items.

With this questionnaire, we observed whether methods and forms of OSH education are at an adequate level from the pupils 'perspective. We also wanted to find out how pupils can apply their theoretical knowledge in practice. The questionnaire consisted of 17 closed questions. Respondents answered according to their agreement or disagreement with the given items on a 5-point Likert scale, starting from "1 - yes", "2 - somewhat yes", "3 
- maybe", "4 - somewhat not" up to "5 - no". In a 5point Likert scale, the mean value always expresses indecisiveness (e.g., "I cannot decide" or "I agree but also disagree"), and it is the most frequent tool for measuring people's attitudes and opinions [20], [21]. The questionnaire was anonymous. The complete questionnaire items together with answers are in Table 1 [22].

Table 1. Questionnaire survey and respondents 'results

\begin{tabular}{|c|c|c|c|c|c|c|}
\hline No. & The wording of the question & 1 & 2 & 3 & 4 & 5 \\
\hline 1. & $\begin{array}{l}\text { Do you think that you acquired adequate theoretical knowledge in } \\
\text { the field of Occupational Safety and Health (OSH) during your } \\
\text { studies? }\end{array}$ & 55 & 26 & 15 & 2 & 2 \\
\hline 2. & $\begin{array}{l}\text { Was the level of the theoretical OSH preparation complying with } \\
\text { practice? }\end{array}$ & 63 & 21 & 13 & 0 & 2 \\
\hline 3. & $\begin{array}{l}\text { Were you adequately informed about your rights from the OSH } \\
\text { perspective? }\end{array}$ & 61 & 20 & 8 & 8 & 3 \\
\hline 4. & $\begin{array}{l}\text { Were you adequately informed about your duties at the workplace } \\
\text { from the OSH perspective? }\end{array}$ & 75 & 20 & 3 & 0 & 2 \\
\hline 5. & $\begin{array}{l}\text { Did you meet with good practice examples during your studies on } \\
\text { avoiding accidents in your study field? }\end{array}$ & 40 & 26 & 13 & 7 & 14 \\
\hline 6. & $\begin{array}{l}\text { Did you train safe ways how to operate machines or hand tools in } \\
\text { practice? }\end{array}$ & 66 & 19 & 7 & 5 & 3 \\
\hline 7. & Was the obtained information adequately understandable for you? & 68 & 21 & 9 & 0 & 2 \\
\hline 8. & Did you meet with cases of alcohol drinking at your workplace? & 10 & 1 & 6 & 7 & 76 \\
\hline 9. & $\begin{array}{l}\text { Was the result of risk assessment at practical work part of the } \\
\text { training? }\end{array}$ & 29 & 12 & 26 & 10 & 23 \\
\hline 10. & $\begin{array}{l}\text { Do you know which hazard is the most significant in your } \\
\text { profession? }\end{array}$ & 45 & 19 & 15 & 6 & 12 \\
\hline 11. & $\begin{array}{l}\text { Do you think that your working conditions are satisfactory from } \\
\text { the OSH perspective? }\end{array}$ & 69 & 15 & 13 & 1 & 3 \\
\hline 12. & $\begin{array}{l}\text { Do you agree with the following statement: ,Keeping OSH } \\
\text { regulations contributes to making your work more efficient, } \\
\text { decreasing the number of work accidents and the incidence of } \\
\text { occupational illnesses? " }\end{array}$ & 59 & 13 & 15 & 6 & 7 \\
\hline 13. & $\begin{array}{l}\text { Do you know which personal protective equipment you have to } \\
\text { use at work? }\end{array}$ & 73 & 17 & 8 & 1 & 1 \\
\hline 14. & $\begin{array}{l}\text { Do you consider your workplace satisfactory to your needs and } \\
\text { performed work? }\end{array}$ & 73 & 11 & 8 & 4 & 4 \\
\hline 15. & Was the $\mathrm{OSH}$ training attractive and interesting? & 25 & 13 & 31 & 12 & 19 \\
\hline 16. & Do you know what to do in the case of an accident? & 54 & 22 & 16 & 1 & 7 \\
\hline 17. & $\begin{array}{l}\text { Were you demonstrably examined in legal regulations before } \\
\text { taking up your work (e.g. with a test or examination)? }\end{array}$ & 57 & 13 & 16 & 1 & 13 \\
\hline
\end{tabular}

\section{Results}

In our research, participated pupils studying in four-year or three-year study fields and one pupil from the post-secondary study. There were first graders, second graders and third graders. Out of 13 study fields provided at school, in our questionnaire were pupils from eight study fields. Figure 2 depicts the age groups of pupils who filled in our questionnaire.

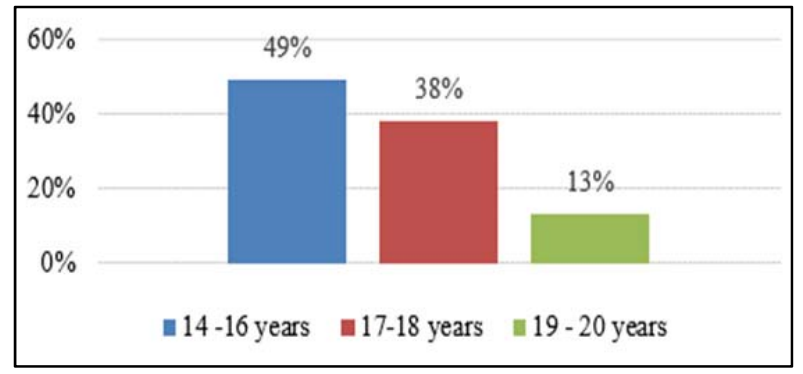

Figure 2. Age range of respondents participating in the questionnaire survey

In our questionnaire survey, $49 \%$ of the youngest pupils participated. The least interested were the oldest pupils (13\%). According to the obtained results, our respondents were pupils from four-year study fields. All pupils are included in the dual education system.

Figure 3 depicts the percentage participation of respondents according to their study fields.

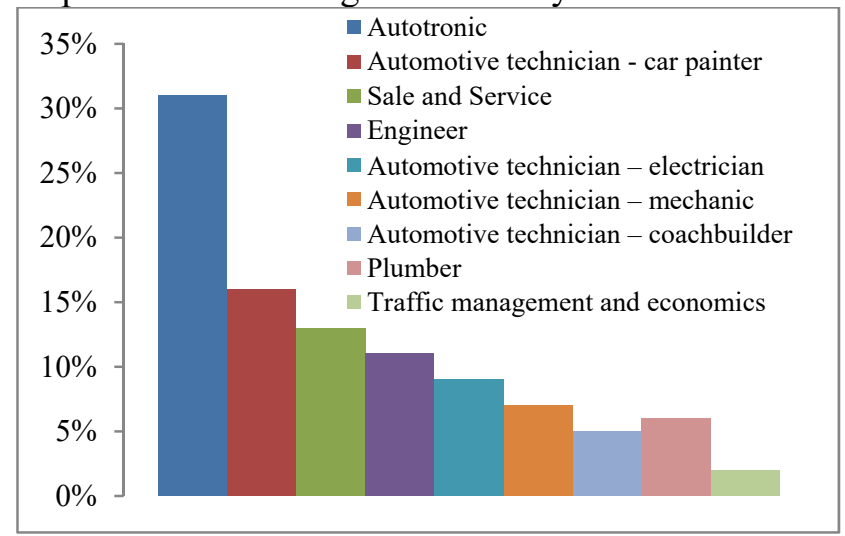

Figure 3. Respondents participating in the survey according to their study fields

From the results mentioned above, it is evident that pupils are primarily interested in the profession of an autotronic. When they successfully finish their studies, pupils preparing for this profession become qualified workers who have general educational bases joined with vocational theoretical knowledge, and within the dual education, they also acquired practical skills. When these pupils pass adequate introductory schooling and practice, they can independently perform various automotive industry activities. They are employable and required in the labour market.

\section{Discussion}

More than $80 \%$ of respondents answered positively to the first three questions concerning the $\mathrm{OSH}$ theoretical knowledge quality. To the fourth question with the wording "Were you adequately informed about your duties at the workplace from the $\mathrm{OSH}$ perspective?", up to $95 \%$ of respondents answered "yes" or "somewhat yes".

However, to the following question "Did you meet with good practice examples during your studies on avoiding accidents in your study field?", we did not obtain clear answers from pupils. 13\% of pupils do not know about good practice examples as a motivation for their work. $21 \%$ of pupils mention that they were not informed about good practice examples as a tool for preventing accidents. The European Agency for Safety and Health at Work (OSHA) has prepared a series of interesting short films for educators, focusing on specific areas, which can also be used in practical training (https://www.napofilm.net/en/learning-with- napo / napo-for-teachers). It is important to provide safety training for young people provided by employers' lecturers who adapt the didactic tools and choice of 
methods so that the lectures are engaging, interactive and age appropriate.

In the following two answers, respondents confirmed that they were trained how to operate machines and hand tools and that these pieces of information were understandable for them.

In question no. 8 concerning alcohol drinking at the employer's workplace, $11 \%$ of respondents confirmed having a negative experience. This fact is in complete contradiction with the OSH regulations. This offence is classified as a severe offence. It is the reason for the termination of the employment relationship in the case of its confirmation.

Within the OSH training, pupils of secondary vocational schools should learn how to identify possible risks and know how to minimise them. This obligation arises from the OSH legislation. For this reason, question no. 9 focused on the analysis of acquired knowledge from the OSH training. Pupils meet with new technological equipment, changes in working conditions, and changes in used materials, proper production processes, or work procedures during practical lessons. For this reason, pupils should be able to follow these changes so that they could fulfil their new working tasks and, primarily, they should cope with these changes safely. Thus, they should be able to recognise and assess all possible risks. The risk assessment at the pupils' workplaces for vocational preparation need not be absent in the training's contents. One of our recommended measures is the inclusion of this lack in pupils 'education and formation.

Subsequently, in their answers to the following question whether they can identify the most significant risk at work, $64 \%$ of respondents said they know it, $15 \%$ of pupils were not sure about it and $18 \%$ did not know this risk. If they do not know what hazard they are exposed to, they cannot prevent this risk. In this way, their safety is at risk, and the safety of other people at the given workplace too. Thus, it is crucial to improve the OSH education aimed at pupils from secondary vocational schools. OSH education should focus on their knowledge of the most significant hazards and risks arising from them.

$84 \%$ of pupils evaluated working conditions as satisfactory. $72 \%$ of respondents agreed that keeping legal regulations in the $\mathrm{OSH}$ field contributes to decreasing occupational accidents and illnesses. Pupils answered question no.13 positively, where up to $90 \%$ of respondents knew what personal protective equipment they must use at work.

They also answered question no.14 positively. Here respondents more or less positively evaluated the quality of the environment where they perform their work activity.
However, the question concerning OSH training`s attractivity is not attractive or interesting from the pupils perspective. Only 38\% of pupils answered this question positively. $31 \%$ of respondents could not decide, and the same percentage of pupils marked it negatively. The obtained results point to the fact that training designed for young people should be attractive. It should be adjusted to this target group's age and needs, employing available modern educational tools and good practice examples.

The following question about first aid confirmed that $66 \%$ of respondents would probably know how to provide first aid. Despite this fact, $34 \%$ of pupils did not know or were not sure if they could provide first aid in case of emergency.

In their last answer, $70 \%$ of respondents mentioned that they had an examination about their OSH knowledge, $14 \%$ of pupils said their knowledge was not verified, and $16 \%$ do not remember it.

The survey found the following positives regarding the initial training of students before entering the workplace:

- they acquire theoretical knowledge in the field of Occupational safety and health at work, including their rights and obligations;

- part of the training is also preparation for a specific place of work, including the operation of machines, tools and equipment;

- they are aware of their rights and obligations;

- they consider their workplaces to be satisfactory;

- they can provide first aid in the event of an accident;

- they use appropriate personal protective equipment.

However, the following issues were identified from the responses:

- the training is not interesting enough, examples of good practice are lacking and probably not adapted to the age category of the pupils;

- many respondents do not know the result of the risk analysis that forms the basis of the practical training;

- Many students are unable to identify the most significant hazards at work.

By results analysing the questionnaire can also reflect on the question asked.

The first question "What is the main goal of education health and safety of students in dual education?" can be said that the main objective of the safety system is prevention - to know the hazards and risks. This means that risk education has to be part of every education. The results clearly point to the fundamental absence of the main topic in education [23]. 
In the second research question "Are examples of good practice prevention against injuries?", the practice clearly confirms this fact. Appropriately shared real results, accident statistics with an explanation of the root causes of accidents are a tool to reduce injuries. This area is also not sufficiently developed in VET education [24], [25].

The uninterestingness of the training is the answer to the research question "Are the forms and methods of education adapted to the age of educators?". One of the facts could also be inappropriate or incorrectly applied forms and methods of education [26].

According to the authors (Kordošová \& Urdziková), it can be stated that secondary schools in the Slovak Republic lack a subject that would lead to a culture of safety in the context of preparation for future professions. Companies' educators are oriented by their educational activities on adults. Didactic materials and methods and forms of training may not correspond to adolescents entering dual education. In previous studies (Tureková \& Bagalová) it was also found that the results of risk management are missing in the study documents.

\section{Conclusion}

Our questionnaire survey aimed to determine the level of introductory training and conditions from the OSH perspective at a chosen secondary vocational school in the dual education system. A positive survey finding was that pupils are satisfied with the level of knowledge they acquire during the introductory training. On one side, a questionnaire is a method that quickly obtains many data. On the other side, respondents express there their subjective opinions. This fact was confirmed in crucial answers, e.g. the ignorance of significant risks, verifying acquired knowledge after the training or the risk management in activities with the equipment they work with at the workplace. For this reason, it is indispensable to introduce an independent school subject of OSH at secondary vocational schools preparing pupils for future professions. Pupils should know the basic principles of protecting their health and the health of their colleagues. At the same time, they should have thorough knowledge about occupational safety when they work with various work equipment, tools, machines and technologies.

Currently, introductory OSH training and retraining are under employers' responsibility. However, there arises a question about their adjustment to pupils' needs. There is a lack of highquality schooling materials, too. If there is an $\mathrm{OSH}$ subject included in the theoretical education, pupils would know the fundamental OSH regulations before starting their practical lessons, and employers could spend more time dealing with specific safety measures concerning the given workplace.

The legislation clearly stipulates that training on hazards and risks at work should also be the subject of notification. This information is either insufficiently incorporated or missing from induction training. It is necessary that the lifelong learning of trainers includes risk prevention and their implementation in every activity.

\section{Acknowledgement}

The authors gratefully acknowledge the contribution of the KEGA Grant Agency of the Slovak Republic under the KEGA Project no. 014UKF-4/2020 "Innovative learning e-modules for safety in dual education".

\section{References}

[1]. Remington, T. F. (2017). Public-Private Partnerships in VET: Translating the German Model of Dual Education. RePEc (Research Papers in Economics). Retrieved from: https://ioe.hse.ru/data/2017/12/04/1161471095/Remin gton\%20T.F..pdf [accessed: 15 May 2021].

[2]. Hrmo, R., Miština, J., \& Krištofiaková, L. (2016). Improving the quality of technical and vocational education in Slovakia for European labour market needs. International Journal of Engineering Pedagogy (iJEP), 6(2), 14-22.

[3]. Dustmann, C., \& Schönberg, U. (2012). What makes firm-based vocational training schemes successful? The role of commitment. American Economic Journal: Applied Economics, 4(2), 36-61.

[4]. Simonics, I. (2020). Relationships Among Economy, Industry, Vocational Education and Training and Higher Engineering Education-The Trefort Project Editorial. Int. J. Eng. Pedagog., 10(5), 4-6.

[5]. Hanushek, E. A. (2012). Dual education: Europe's secret recipe?. In CESifo forum (Vol. 13, No. 3, pp. 29-34). München: ifo Institut-Leibniz-Institut für Wirtschaftsforschung an der Universität München.

[6]. Hanushek, E. A. (2012). Dual education: Europe's secret recipe?. In CESifo forum (Vol. 13, No. 3, pp. 29-34). München: ifo Institut-Leibniz-Institut für Wirtschaftsforschung an der Universität München.

[7]. Act no. 61/2015 Coll., (2015). on Vocational Education and Training and on Amendments to Certain Acts. Retrieved from: https://www.zakonypreludi.sk/zz/2015-61 [accessed: 10 April 2021].

[8]. Határ, C., Rosinský, R. (2019). Sociálne kompetencie a nevhodné správanie žiakov. Slavonic Pedagogical Studies Journal, 8(1), 257-268.

[9]. ŠIOV., (2019).Manuál implementácie SDV pre zamestnávatela, strednú odbornú školu a zriad'ovatel'a. Bratislava, $139 \mathrm{p}$.

[10]. Petríková, M. Duffeková, M., Holzhauser, G. (2015). Čo sme kvantitatívne nemerali: prípadové štúdie o spolupráci stredných odborných škôl s firmami. SIOV. Bratislava, $71 \mathrm{p}$. 
[11]. Hricová, R. Madzinová, R. (2018). Dual education as a tool to improve structural needs of the labour market. RELIK 2018: the 11th international scientific conference. Praha: VŠE v Praze, Oeconomica Publishing House, 106-118.

[12]. Barnová, S., Krásna, S., \& Gabrhelová, G. (2020). Dual system of vocational education and training in Slovakia. INTED2020 Proceeding, Valencia, 45924596.

[13]. ŠIOV. (2019). Occupational safety and health with practical training with an employer. Retrieved from: http://dualnysystem.sk/wpcontent/uploads/2019/04/BOZP-pri-PV-uzamestnavatela.pdf [accessed 19 June 2021]

[14]. Rauner, F. (2007). Vocational education and training-A European perspective. In Identities at work (pp. 115-144). Springer, Dordrecht.

[15]. Temiaková, D. (2018). Classification of work activities of an adult education manager. Andragogické štúdie 2018. Banská Bystrica: Belianum, 139-146.

[16]. Gómez, M. Á., Herrera, R. F., Atencio, E., \& Munoz-La Rivera, F. C. (2021). Key Management Skills for Integral Civil Engineering Education. Int. J. Eng. Pedagog., 11(1), 64-77.

[17]. Kordošová, M., Urdziková, J. (2017). Komparatívna analýza systému výchovy a vzdelávania $k$ BOZP $v$ školskom vzdelávaní vo vybraných krajinách EÚ. Bratislava, IVPP. 98 p.

[18]. Forster, A. G., \& Bol, T. (2018). Vocational education and employment over the life course using a new measure of occupational specificity. Social Science Research, 70, 176-197.
[19]. Gadusova, Z., Haskova, A., \& Predanocyova, E. (2019). Teachers' professional competence and their evaluation. Образование и саморазвитие, 14(3), 1724.

[20]. Chytrý, V., \& Kroufek, R. (2017). Možnosti využití Likertovy škály-základní principy aplikace V pedagogickém výzkumu a demonstrace na prŕíkladu zjišstování vztahu člověka $\mathrm{k}$ prŕrodě. Scientia in educatione, $8(1)$.

[21]. Tureková, I., \& Bagalová, T. (2018). Knowledge and Experiences of Safety and Health Occupation Risks among Students. International Journal of Engineering Pedagogy, 8(5).

[22]. Zsoldosová., P. (2020). Metódy a formy školení v bezpečnosti práce pri duálnom vzdelávaní. Diploma work. PF UKF v Nitre. 86 p.

[23]. Mkpat, E., Reniers, G., \& Cozzani, V. (2018). Process safety education: A literature review. Journal of Loss Prevention in the Process Industries, 54, 1827.

[24]. Park, Y. (2018). How do specialist teachers practice safety lessons? Exploring the aspects of physical education safety lessons in elementary schools. International Electronic Journal of Elementary Education, 10(4), 457-461.

[25]. Geller, E. S. (2005). Behavior-based safety and occupational risk management. Behavior modification, 29(3), 539-561.

[26]. Lucke, T., Dunn, P. K., \& Christie, M. (2017). Activating learning in engineering education using ICT and the concept of 'Flipping the classroom'. European Journal of Engineering Education, 42(1), 45-57. 